\title{
Nitrogen fertilization strategies for improved Mediterranean rainfed wheat and barley performance and water and nitrogen use efficiency
}

\author{
Daniel Plaza-Bonilla $^{\mathrm{a}, *}$, Jorge Lampurlanés ${ }^{\mathrm{b}}$, Fabián G. Fernández ${ }^{\mathrm{c}}$, Carlos Cantero-Martínez ${ }^{\mathrm{d}}$ \\ ${ }^{a}$ Department of Crop and Forest Sciences, Agrotecnio, Universitat de Lleida, Av. Alcalde Rovira Roure, 191, 25198, Lleida, Spain \\ ${ }^{\mathrm{b}}$ Departamento de Ingeniería Agroforestal, Unidad Asociada EEAD-CSIC, Agrotecnio, Universitat de Lleida, Av. Alcalde Rovira Roure, 191, 25198, Lleida, Spain \\ c University of Minnesota, 1991 Upper Buford Circle, St. Paul, MN, 55108, United States \\ d Department of Crop and Forest Sciences, Associated Unit EEAD-CSIC, Agrotecnio, Universitat de Lleida, Av. Rovira Roure, 191, 25198, Lleida, Spain
}

\section{A R T I C L E I N F O}

\section{Keywords:}

Fertilizer incorporation

No-tillage

Organic fertilizers

Top-dress fertilization

Water limitation

\begin{abstract}
A B S T R A C T
Adequate fertilization strategies are paramount to fulfill increasing demands for food, feed and fiber while reducing environmental impacts. However, their optimization under Mediterranean no-till systems has received little attention. The objective of this work was to assess winter cereal yield and water and $\mathrm{N}$ use efficiencies in a rainfed semiarid Mediterranean climate under (i) a range of pre-plant fertilizers [control without $\mathrm{N}$ fertilizer $(0 \mathrm{~N})$, and the following at $75 \mathrm{~kg} \mathrm{~N} \mathrm{ha}^{-1}$ : mineral $\mathrm{N}$ (MIN), swine slurry (SS), poultry manure (PM), and compost $(\mathrm{COM})$ ], (ii) fertilizer incorporation: no-tillage without incorporating (NT) or incorporation with a vibrocultivator (INC) and (iii) application of urea-ammonium nitrate solution (UAN) as top-dress as a control without UAN (UAN-) or $50 \mathrm{~kg} \mathrm{~N} \mathrm{ha}^{-1}$ (UAN+). The experiment covered six cropping seasons (2012-2019).

Pre-plant applications had similar responses in crop yield, biomass, $\mathrm{N}$ uptake, grain $\mathrm{N}$, water-use efficiency for biomass $\left(W_{U} E_{b}\right)$, and water-use efficiency for yield $\left(W_{U} E_{y}\right)$ but were greater than $0 \mathrm{~N}$. The lack of differences between pre-plant fertilizers would be explained by the high amount of residual $\mathrm{N}$ and the mineralized $\mathrm{N}$ during

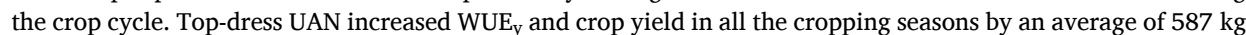
grain $\mathrm{ha}^{-1}$, which represented $18 \%$ of the total annual production. Averaged across variables and the growing seasons, INC reduced soil water content and WUE by $10 \%$ (from 24.3 to $21.8 \mathrm{~kg} \mathrm{ha}^{-1} \mathrm{~mm}^{-1}$ ). Also, INC reduced grain yield by $9 \%$ (from 3799 to $3450 \mathrm{~kg} \mathrm{ha}^{-1}$ ) by reducing the number of spikes $\mathrm{m}^{-2}$ produced, pointing out that INC resulted in water deficit during the early reproductive period of the crop. While INC is often consider a best management practice to reduce $\mathrm{NH}_{3}$ volatilization losses from broadcast fertilizer applications, the results demonstrate that in rainfed Mediterranean agroecosystems water is more limiting than the $\mathrm{N}$ that could be potentially lost by volatilization.
\end{abstract}

\section{Introduction}

The sustainable use of $\mathrm{N}$ fertilizers is key for maintaining a growing population while avoiding losses of reactive $\mathrm{N}$ to the environment such as nitrate leaching, ammonia volatilization and nitrous oxide emission to the atmosphere (Mosier, 2002). Moreover, $\mathrm{N}$ fertilization represents a major cost for field crop production (e.g. Maresma et al., 2016) and its management is key in rainfed areas, where crop growth, $\mathrm{N}$ mineralization dynamics, $\mathrm{N}$ uptake and $\mathrm{N}$ losses strongly depend on the magnitude and distribution of precipitation. Rainfed agriculture is the dominant crop and forage production system throughout the world with around 80 $\%$ of the global surface (Hatfield et al., 2001; Rockström and Karlberg, 2009). A proper nitrogen rate is difficult to estimate in many rainfed areas due to precipitation unpredictability. Moreover, low productivity in arid and semiarid rainfed areas forced farmers to diversify their sources of revenue by focusing on animal production. Traditional livestock farms have undergone drastic intensification leading to a high concentration of animals in rural areas (Sánchez-Bascones et al., 2019).

\footnotetext{
Abbreviations: 0N, control without N; COM, compost; HI, harvest index; INC, incorporation of urea-ammonium nitrate with a 5-cm depth pass of a vibrocultivator;

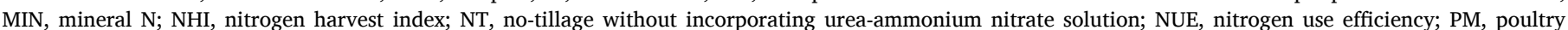

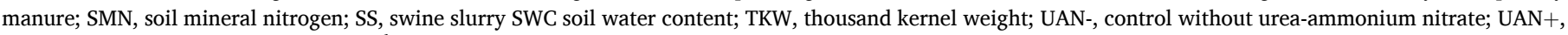
urea-ammonium nitrate at $50 \mathrm{~kg} \mathrm{~N} \mathrm{ha}^{-1}$; WU, water use; $\mathrm{WUE}_{\mathrm{b}}$, water-use efficiency for biomass; WUE $\mathrm{E}_{\mathrm{y}}$, water-use efficiency for yield.

* Corresponding author.

E-mail address: daniel.plaza@udl.cat (D. Plaza-Bonilla).
} 
One example of such change through intensification is the Ebro valley, an important agricultural region located in NE Spain. Cropping systems in the rainfed areas of the valley are based in the cultivation of winter cereals such as soft wheat (Triticum aestivum L.) and barley (Hordeum vulgare L.), although a recent EU Common Agricultural Policy reform (European Parliament and Council of the European Union, 2013) has moved farmers to the cultivation of alternative crops such as winter pea (Pisum sativum L.) and canola (Brassica napus L.). The low profitability of field crops in this dry region led to the establishment of large facilities for animal production during the last three decades (Clar and Pinilla, 2011) especially focused on swine (Sus scrofa domesticus) finishing, poultry (Gallus gallus domesticus) and cattle (Bos taurus) as a way to increase farmer's revenue. The large concentration of farms in the area and the limited land availability led to application of swine slurry at amounts far beyond crop N needs (Guillaumes et al., 2006). This behavior has led to the declaration of several nitrate vulnerable zones, according to the EU regulations (European Union, 1991).

In areas with intensive livestock production such as the eastern Ebro valley, the large availability of organic residues from livestock facilities has led to the development of strategies based on the circular economy (CE) concept. Circular economy aims at overcoming the traditional production and consumption pattern based on continuous growth and increasing resource performance (Noya et al., 2017). One clear example of the application of the CE concept would be the establishment of cogeneration plants. During the production of biogas, these plants use the surplus of thermal energy to dry the solid fraction of digestate (Sánchez-Bascones et al., 2019). The solid fraction of digested swine slurry has higher concentration of total and organic nitrogen compared to the raw material (Nkoa, 2004). Since most of the $\mathrm{N}$ content is based on organic forms, digestates and other solid organic fertilizers such as composts or manure must be mineralized before becoming available to crops. The application of solid fertilizers to the soil usually leads to improvements in soil structural stability and breakdown resistance of soil aggregates (Plaza-Bonilla et al., 2013). However, contradictory effects of anaerobic digestates and other types of solid fertilizers on crop growth and yield have been reported (Möller and Müller, 2012).

In the Ebro valley, a significant proportion of the agricultural surface has been converted to no-till (NT) in the last three decades, which has reduced fuel consumption, labor costs and time, and allow farmers to increase area under cultivation (Kassam et al., 2009). The benefits of NT in the rainfed arid and semiarid area of the Ebro valley in terms of soil water storage, greater crop yields and greater water and $\mathrm{N}$ use efficiencies, have been highlighted by several studies (e.g. Lampurlanés et al., 2016; Plaza-Bonilla et al., 2017). In the context of NT in dry soils, broadcasting of $\mathrm{N}$ fertilizers on the soil surface is almost ubiquitous in this region. While the impacts of liquid manure application have been widely studied under conventional tillage, the same is not true for NT (Chen and Samson, 2002). Application of $\mathrm{N}$ fertilizers on the soil surface usually leads to high ammonia volatilization losses (Sommer et al., 1991) and undesirable odors causing tensions between farmers and urban populations (Parker et al., 2013). A potential approach to circumvent these problems in NT would be to inject slurry. For instance, Malhi et al. (1996) observed lower ${ }^{15} \mathrm{~N}$ recovery in barley when broadcasting $\mathrm{N}$ fertilizer because of higher losses through ammonia volatilization compared to banding close to the seed-row under conventional tillage "(but see Velthof and Mosquera, 2011)".

The objective of this experiment was to assess the impact of different $\mathrm{N}$ fertilization strategies based on different pre-plant fertilizers, incorporation of the fertilizers and use of UAN as top dressing on winter cereals yield and water and $\mathrm{N}$ use efficiency. Our hypothesis was that the use of organic fertilizers could attain similar crop yield levels and water and $\mathrm{N}$ use efficiencies as mineral $\mathrm{N}$ fertilizer and that the incorporation of fertilizers would increase yield and water and $\mathrm{N}$ use efficiencies.

\section{Materials and methods}

\subsection{Experimental site and treatments}

A static field experiment was established in October 2012 in Coscó (Oliola) (NE Spain, $41^{\circ} 48^{\prime} 43^{\prime \prime} \mathrm{N}, 1^{\circ} 09^{\prime} 59^{\prime \prime} \mathrm{E}$ ) in a rainfed area with a temperate continental Mediterranean climate. Soil and climate characteristics of the site are shown in Table 1 and Fig. 1, respectively. Before the experiment the site was managed with a winter cereal rotation under NT and the use of a pre-emergence non-selective herbicide application (1.5 L $36 \%$ glyphosate $\mathrm{ha}^{-1}$ ) for weed control.

The experimental design consisted of the combination of (i) a range of pre-plant fertilizers [control without $\mathrm{N}$ fertilizer $(0 \mathrm{~N})$, and the following at $75 \mathrm{~kg} \mathrm{~N} \mathrm{ha}^{-1}$ (considered the optimum for the conditions of the experiment): mineral $\mathrm{N}$ (MIN), swine slurry (SS), poultry manure $(\mathrm{PM})$, and compost $(\mathrm{COM})]$, (ii) fertilizer incorporation: no-tillage without incorporating (NT) or incorporation with a 5-cm depth pass of a vibrocultivator (INC) and (iii) application of urea-ammonium nitrate solution (UAN) as top-dress at the beginning of tillering as a control without UAN (UAN-) or $50 \mathrm{~kg} \mathrm{~N} \mathrm{ha}^{-1}$ (UAN+) arranged in a split-strip block design with three blocks. The pre-sowing fertilization strategies were assigned to the main plot, the incorporation strategies to the subplot and the top dressing fertilization strategies to a strip perpendicular to the other factors. Main plot size was $40 \mathrm{~m} \times 12 \mathrm{~m}$, subplot size was $40 \mathrm{~m} \times 6 \mathrm{~m}$ and strip-plot size was $20 \mathrm{~m} \times 6 \mathrm{~m}$.

The MIN treatment was surface broadcast ammonium sulphate $(21 \%$ $\mathrm{N})$. The SS treatment was swine slurry from a nearby finishing commercial farm with a composition of 1.70-2.23 \% N, 2.15-3.52\% P and $3.90-4.03 \% \mathrm{~K}$. The slurry was spread with a commercial vacuum tanker fitted with a splashplate (Gili, mod. CB-18, Montgai, Spain). The PM treatment consisted of manure from a nearby broiler farm with a composition of 2.65-3.62 \% organic N, 1.86-1.99\% P, and 2.78-3.94 \% $\mathrm{K}$. The COM treatment varied slightly in composition among cropping seasons: dry pellets from swine manure anaerobic digestion + evaporation + thermal drying with a composition of $1.86 \% \mathrm{~N}$, $2.57 \% \mathrm{P}$ and $1.86 \% \mathrm{~K}$ in 2012-2013 and 2013-2014 (Tracjusa, Juneda Spain), and composted organic material with a composition of $3.0 \% \mathrm{~N}$, $3 \% \mathrm{P}_{2} \mathrm{O}_{5}$ and $2 \% \mathrm{~K}_{2} \mathrm{O}$ produced by Guardia Compo (Foradada, Spain) in 2014-2015, 2015-2016 and 2016-2017 and VERFOR- FR 55-322, produced by Inprog (Alcoletge, Spain) in 2017-2018 and 2018-2019 cropping seasons. Poultry manure and COM were applied with the use of a manual fertilizer spreader. The analysis of the organic products was used to calculate the application rate to be equivalent to $75 \mathrm{~kg} \mathrm{~N}^{-1}$.

Table 1

General and soil $(0-34 \mathrm{~cm})$ characteristics of the Ap horizon of the field site. Soil properties were measured at the beginning of the experiment (October 2012).

\begin{tabular}{|c|c|}
\hline \multicolumn{2}{|l|}{ Site and soil characteristic } \\
\hline Elevation (masl) & 428 \\
\hline Annual precipitation (mm) & 435 \\
\hline Mean annual air temperature $\left({ }^{\circ} \mathrm{C}\right)$ & 12.9 \\
\hline Annual PET (mm) & 1077 \\
\hline Dryland subtype & Semiarid \\
\hline Soil classification ${ }^{4 \pi}$ & Typic Xerofluvent \\
\hline $\mathrm{pH}\left(\mathrm{H}_{2} \mathrm{O}, 1: 2.5\right)$ & 8.3 \\
\hline $\mathrm{EC}_{1.5}\left(\mathrm{dS} \mathrm{m} \mathrm{m}^{-1}\right)$ & 0.19 \\
\hline Organic C $\left(\mathrm{g} \mathrm{kg}^{-1}\right)$ & 9.1 \\
\hline Organic $N\left(\mathrm{~g} \mathrm{~kg}^{-1}\right)$ & 1.4 \\
\hline $\mathrm{CaCO}_{3}\left(\mathrm{~g} \mathrm{~kg}^{-1}\right)$ & 280 \\
\hline \multicolumn{2}{|l|}{ Particle size distribution (\%) } \\
\hline Sand $(2000-50 \mu \mathrm{m})$ & 16.3 \\
\hline Silt $(50-2 \mu \mathrm{m})$ & 63.5 \\
\hline Clay $(<2 \mu \mathrm{m})$ & 20.2 \\
\hline
\end{tabular}

PET, potential evapotranspiration.

" According to the Aridity index (quotient between precipitation and PET) (Cherlet et al., 2018).

ๆๆ According to the USDA classification (Soil Survey Staff, 2014). 

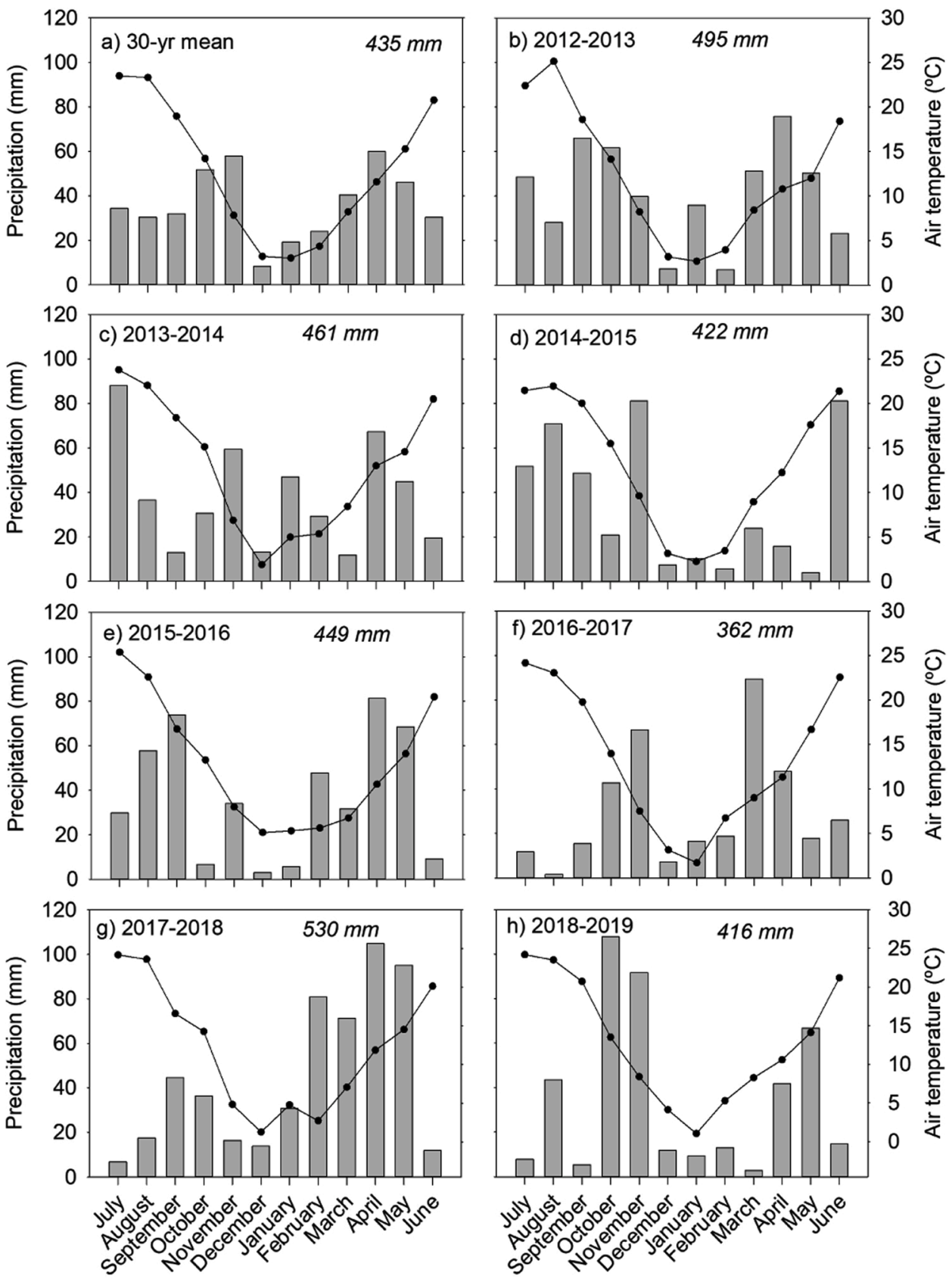

Month

Month

Fig. 1. Monthly precipitation (bars) and air temperature (solid black line) at the experimental site: (a) historical (30-year) mean (1989-2019) and (b) 2012-2013, (c) 2013-2014, (d) 2014-2015, (e) 2015-2016, (f) 2016-2017, (g) 2017-2018, and (h) 2018-2019 cropping seasons. Total annual precipitation is shown in italics.

UAN was applied with a liquid fertilizer sprayer equipped with 5-orifice nozzles.

Crop rotation during the experiment consisted of barley (Hordeum vulgare L.) (2012-2013) - soft wheat (Triticum aestivum L.) (2013-2014) - barley (2014-2015 and 2015-2016) - soft wheat (2016-2017) - winter pea (Pisum sativum L.) (2017-2018) - and soft wheat (2018-2019). No tillage was carried out in the experiment, relying solely on a preemergence non-selective herbicide application (1.5 L $36 \%$ glyphosate $\mathrm{ha}^{-1}$ ) for weed control. Crop sowing was done between October and November with a direct-drilling disk machine to a depth of $3-4 \mathrm{~cm}$. Daily air temperature and rainfall data were recorded with a datalogger (Em50 $\mathrm{ECH}_{2} \mathrm{O}$ Logger, METER Group, München, Germany) from an automated weather station located on the site.

\subsection{Soil and crop samplings and analyses}

An ATV equipped with a hydraulic soil corer was used each season to obtain two samples per plot to determine soil water content (SWC) and mineral $\mathrm{N}$ contents (SMN) from the $0-30$ and $30-60 \mathrm{~cm}$ depth increments at three stages: before sowing (mid-September - midOctober), at the end of winter and before the application of top-dressing fertilizer (mid-January - mid-February), and after harvest (end of June mid-July). Soil water content was determined gravimetrically by drying the soil samples at $105{ }^{\circ} \mathrm{C}$ for $48 \mathrm{~h}$ until equilibrium. Soil mineral nitrogen was determined as soil nitrate by extracting $50 \mathrm{~g}$ of field-moist soil with $100 \mathrm{ml}$ of $1 \mathrm{M} \mathrm{KCl}$, filtering, and analyzing the extracts with a continuous flow analyzer (Seal Autoanalyzer 3, Seal Analytical, Norderstedt, Germany). Soil ammonium can be considered negligible in the 
area of the experiment, given the high oxidative conditions, where $\mathrm{NH}_{4}^{+}$ concentrations are usually very low (i.e. $<2 \%$ of total soil mineral $N$ ) (Angás et al., 2006). Concentration values were converted to mass-based values assuming a soil bulk density of $1.4 \mathrm{~g} \mathrm{~cm}^{-3}$ (Plaza-Bonilla et al., 2010).

Biomass samples were collected right before harvest by cutting plants at the soil surface in three $0.5 \mathrm{~m}$ crop-row lengths to create one composite sample per plot that was partitioned into ears and the rest of the above-ground biomass. Samples were oven-dried at $65^{\circ} \mathrm{C}$ for $48 \mathrm{~h}$ to determine dry mass and spikes were counted, threshed and the number of grains counted and weighed to allow calculation of crop harvest index (HI) and yield components: spikes $\mathrm{m}^{-2}$, kernels spike ${ }^{-1}$ and mass kernel ${ }^{-1}$ from thousand kernels weight (TKW). Grain was harvested with a commercial combine equipped with residue choppers that allowed uniform spread of crop residues over the soil surface and grain yield was corrected to $100 \mathrm{~g} \mathrm{~kg}^{-1}$ moisture. Grain, stem and leaf $\mathrm{N}$ concentration was determined by dry combustion (Dumas method) with a LECO-2000 analyzer (LECO, St Joseph, MI, US). N uptake was calculated as the sum of $\mathrm{N}$ content in grain, stems and leaves. Grain protein concentration was calculated by multiplying the grain $\mathrm{N}$ concentration by 5.83 (Merrill and Watt, 1973).

\subsection{Water and nitrogen use efficiency}

Water-use efficiency for above-ground biomass $\left(W_{U} E_{b}\right)$ and yield (WUE $)_{y}$ was calculated as the quotient of each fraction and water use, where water use was calculated as the difference between soil water content at sowing and at harvest plus the precipitation received in the cropping period.

Nitrogen use efficiency (NUE) was calculated as the quotient of grain yield and $\mathrm{N}$ use where $\mathrm{N}$ use represents the sum of soil mineral $\mathrm{N}$ content (0-60 cm depth) at sowing plus $\mathrm{N}$ fertilizer applied and $\mathrm{N}$ mineralized. In turn, soil $\mathrm{N}$ mineralization was calculated with the data of the control treatment without $\mathrm{N}$ fertilizer as:

$$
\begin{aligned}
\text { Soil } N \text { mineralization }= & \sum_{i=n}^{n} \frac{\left(S M N_{i+1}-S M N_{i}\right)+N \text { uptake }{ }_{0 N}}{\text { Number of days between consecutive sowings }} \\
& \times 365
\end{aligned}
$$

where $\mathrm{SMN}_{\mathrm{i}+1}$ and $\mathrm{SMN}_{\mathrm{i}}$ is the $\mathrm{SMN}$ content (0-60 cm depth) at sowing of year $i+1$ and $i$, respectively.

The cropping season 2017-2018 was excluded from the estimation of $\mathrm{N}$ mineralization to avoid the interference of $\mathrm{N}_{2}$ fixation by pea in the calculation. Nitrogen harvest index (NHI) was calculated as the quotient of grain $\mathrm{N}$ content and above-ground biomass $\mathrm{N}$ acquisition. Additional calculation details are available in Plaza-Bonilla et al. (2017).

\subsection{Data analysis}

Data were checked for normality by plotting a normal quantile plot. Box-Cox and logarithm transformations were used to normalize yield and soil mineral N, respectively. Analyses of variance were performed for the different variables for a split-strip-block design (Federer and King, 2007). Data were split in two groups when analyzing crop related variables, one group with the seasons cropped with cereals (2012-2013, 2013-2014, 2014-2015, 2015-2016, 2016-2017, and 2018-2019) and another group with the season cropped with winter pea (2017-2018), which was excluded from the analysis. When significant, differences among treatments were identified at 0.05 probability level of significance using a Tukey HSD test. Data analysis was done using JMP Pro 14 (SAS Institute Inc, 2018).

\section{Results}

\subsection{Weather conditions}

Cropping season precipitation ranged between $362 \mathrm{~mm}$ in 2016-17 and $530 \mathrm{~mm}$ in 2017-18. Out of the seven cropping seasons studied four seasons (2012-13, 2013-14, 2015-16, and 2017-18) were above the historic precipitation mean (435 mm) (Fig. 1). The 2012-13, 2015-16 and 2016-17 seasons were characterized by the typical Mediterranean climate pattern of precipitation with peaks in autumn and spring. Above average precipitation in the summer occurred in July in the 2013-14 season and June in the 2014-15 season. Moreover, the 2014-15 season was characterized by very low precipitation during the spring. Differently, the 2018-19 season was characterized by a wet autumn and an average spring. Air temperatures followed the continental Mediterranean pattern with very hot summers and cold winters (Fig. 1).

\section{2. $N$ fertilization strategies impact on soil water and nitrate contents}

Soil water content $(0-60 \mathrm{~cm}$ depth) was significantly affected by the pre-plant fertilization $\times \mathrm{N}$ top dressing $\times$ sampling date interaction, the pre-plant fertilization $\times$ incorporation of the fertilizer $\times$ sampling date interaction, and the pre-plant fertilization $\times$ incorporation $\times$ top dressing interaction (Table 2). A trend of slightly lower SWC was observed in different sampling dates in the $0 \mathrm{~N}$ treatment compared to the rest, which was exacerbated by shallow tillage for fertilizer incorporation (data not shown). Soil mineral nitrogen $(0-60 \mathrm{~cm}$ depth) was affected by the pre-plant fertilization $\times$ incorporation $\times$ top dressing interaction, the top dressing $\times$ sampling date interaction and the pre-plant fertilization $\times$ sampling date interaction (Table 2). Soil mineral nitrogen ranged between $20 \mathrm{~kg} \mathrm{~N} \mathrm{ha}^{-1}$ and $272 \mathrm{~kg} \mathrm{~N} \mathrm{ha}^{-1}$ for the $0 \mathrm{~N}$ and SS treatments, respectively (Fig. 2). The $0 \mathrm{~N}$ treatment maintained the

\section{Table 2}

Analysis of variance of soil water content (SWC) and soil mineral $\mathrm{N}$ content (SMN) $(0-60 \mathrm{~cm}$ depth) as affected by pre-plant fertilization $(0 \mathrm{~N}$, control without $\mathrm{N}$ fertilizer; MIN, mineral $\mathrm{N}$ at $75 \mathrm{~kg} \mathrm{~N} \mathrm{ha}^{-1}$; SS, swine slurry at $75 \mathrm{~kg} \mathrm{~N}$ $\mathrm{ha}^{-1}$; PM, poultry manure at $75 \mathrm{~kg} \mathrm{~N} \mathrm{ha}^{-1}$; COM, compost at $75 \mathrm{~kg} \mathrm{~N} \mathrm{ha}^{-1}$ ), incorporation (NT, no-tillage without incorporating the fertilizers; INC, incorporation of the fertilizer with a 5-cm depth pass of a vibrocultivator), top dressing $\mathrm{N}$ fertilization (UAN-, control without fertilizer; UAN,$+ 50 \mathrm{~kg} \mathrm{~N} \mathrm{ha}^{-1}$ as UAN), date and their interactions.

\begin{tabular}{lll}
\hline Treatments & SWC $(\mathrm{mm})$ & SMN $\left(\mathrm{kg} \mathrm{N} \mathrm{ha}^{-1}\right)$ \\
\hline ON & 89 & 64 \\
MIN & 98 & 116 \\
SS & 95 & 113 \\
PM & 95 & 96 \\
COM & 100 & 92 \\
NT & 98 & 101 \\
INC & 93 & 91 \\
UAN- & 93 & 86 \\
UAN + & 98 & 106 \\
ANOVA (p-values) & & \\
Fertilization (Fert) & $<0.001$ & $<0.001$ \\
Incorporation $($ Inc Tillage $)$ & $<0.001$ & 0.002 \\
Top-dressing (Top) & $<0.001$ & $<0.001$ \\
Date & $<0.001$ & $<0.001$ \\
Fert $\times$ Inc Tillage & 0.031 & 0.129 \\
Fert $\times$ Top & $<0.001$ & $<0.001$ \\
Fert $\times$ Date & $<0.001$ & $<0.001$ \\
Inc Tillage $\times$ Top & 0.131 & 0.125 \\
Inc Tillage $\times$ Date & $<0.001$ & 0.151 \\
Top $\times$ Date & $<0.001$ & $<0.001$ \\
Fert $\times$ Inc Tillage $\times$ Top & 0.001 & 0.020 \\
Fert $\times$ Inc Tillage $\times$ Date & 0.008 & 0.636 \\
Fert $\times$ Top $\times$ Date & $<0.001$ & 0.065 \\
Inc Tillage $\times$ Top $\times$ Date & 0.254 & 0.118 \\
Fert $\times$ Inc Tillage $\times$ Top $\times$ Date & 0.148 & 0.566 \\
\hline
\end{tabular}

Different lower-case letters indicate significant differences between treatments at $P<0.05$. 

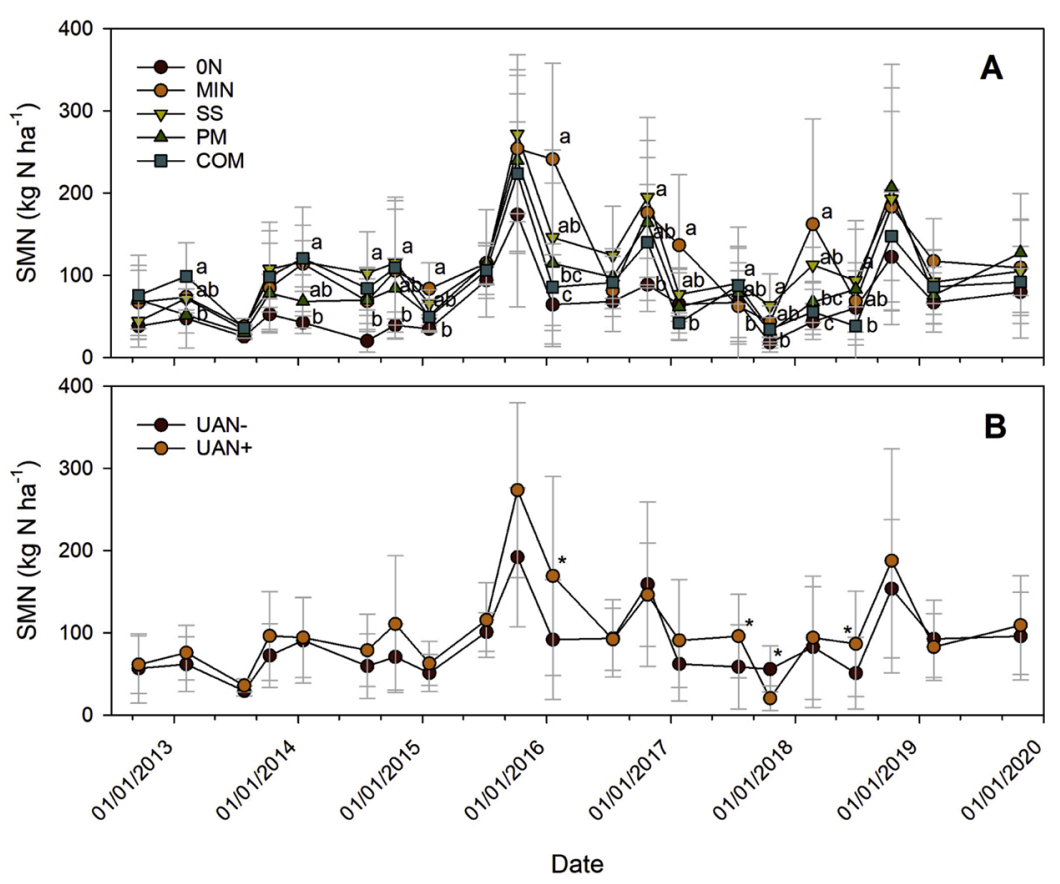

Fig. 2. Soil mineral nitrogen $(S M N)(0-60 \mathrm{~cm}$ depth) as affected by pre-plant fertilization $(0 \mathrm{~N}$, control without $\mathrm{N}$ fertilizer; MIN, mineral $\mathrm{N}$ at $75 \mathrm{~kg} \mathrm{~N}^{-1}$; SS, swine slurry at $75 \mathrm{~kg} \mathrm{~N}^{-1}$ ha, poultry manure at $75 \mathrm{~kg} \mathrm{~N} \mathrm{ha}^{-1}$; COM, compost at $75 \mathrm{~kg} \mathrm{~N} \mathrm{ha}^{-1}$ ) and sampling date (A) and by top dressing $\mathrm{N}$ fertilization (UAN-, control without fertilizer; UAN,$+ 50 \mathrm{~kg} \mathrm{~N} \mathrm{ha}^{-1}$ as UAN) and sampling date (B). Vertical bars correspond to standard deviation. For a given sampling date, different letters (above) or an asterisk (below) indicate significant differences between treatments at $P<0.05$. lowest SMN during the study period, while the COM, SS and MIN treatments showed the highest values, depending on the sampling date (Fig. 2). Slight differences in SMN also occurred between UAN- and UAN + with values $76 \%$ greater under UAN + in the end of winter 2015-16, and $64 \%$ and $71 \%$ greater in the post-harvest samplings in 2016-17 and 2017-18, respectively. Differently, greater SMN was observed in UAN- compared to UAN + in the pre-sowing sampling of 2017-18 (Fig. 2).

\section{3. $N$ fertilization strategies impact on winter cereal grain yield, yield components and grain protein concentration}

Winter cereal grain yield was affected by the pre-plant fertilization $\times$ incorporation $\times$ year interaction and the top dressing $\times$ year interaction (Table 3). Grain yield ranged between $1880 \mathrm{~kg} \mathrm{ha}^{-1}$ for the $0 \mathrm{~N}-\mathrm{NT}$ treatment in $2016-17$ and $6417 \mathrm{~kg} \mathrm{ha}^{-1}$ for the COM-NT treatment in 2018-19 (Fig. 3). In most of the years, significant

Table 3

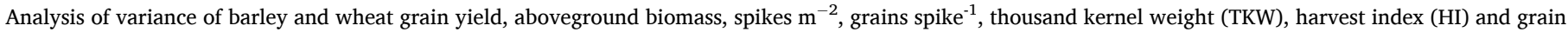

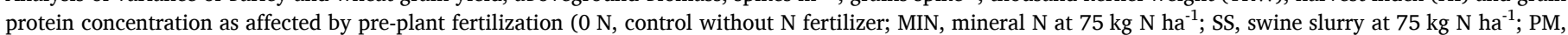

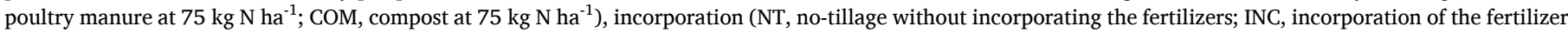

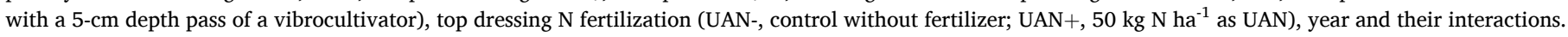

\begin{tabular}{|c|c|c|c|c|c|c|c|}
\hline Treatments & $\begin{array}{l}\text { Grain yield ( } \mathrm{kg} \mathrm{ha}^{-1} \text { at } 10 \% \\
\text { moisture) }\end{array}$ & $\begin{array}{l}\text { Above-ground biomass ( } \mathrm{Mg} \\
\mathrm{ha}^{-1} \text { ) }\end{array}$ & $\begin{array}{l}\text { Spikes } \\
\mathrm{m}^{-2}\end{array}$ & $\begin{array}{l}\text { Grains } \\
\text { spike }^{-1}\end{array}$ & TKW (g) & HI & $\begin{array}{l}\text { Grain protein ( } \\
100 \mathrm{~g}^{-1} \text { ) }\end{array}$ \\
\hline $0 \mathrm{~N}$ & 2881 & 6.17 & 509 & 16.8 & 37.7 & $0.48 \mathrm{a}$ & 10.6 \\
\hline MIN & 4035 & 10.38 & 732 & 19.6 & 36.3 & $0.46 \mathrm{bc}$ & 11.2 \\
\hline SS & 3734 & 9.23 & 728 & 17.7 & 34.9 & $0.44 \mathrm{c}$ & 11.5 \\
\hline PM & 3510 & 7.86 & 619 & 17.9 & 36.9 & $0.47 \mathrm{ab}$ & 10.9 \\
\hline $\mathrm{COM}$ & 3959 & 8.89 & 681 & 18.6 & 36.9 & $0.47 \mathrm{ab}$ & 11.0 \\
\hline NT & 3799 & 8.96 & $676 \mathrm{a}$ & 18.4 & 36.6 & 0.46 & 11.0 \\
\hline INC & 3450 & 8.06 & $632 \mathrm{~b}$ & 17.8 & 36.5 & 0.46 & 11.1 \\
\hline UAN- & 3330 & 7.63 & 615 & 17.1 & 36.5 & 0.46 & 10.6 \\
\hline $\begin{array}{l}\text { UAN+ } \\
\text { ANOVA (p-values) }\end{array}$ & 3917 & 9.39 & 692 & 19.1 & 36.6 & 0.46 & 11.4 \\
\hline Fertilization (Fert) & $<0.001$ & $<0.001$ & $<0.001$ & $<0.001$ & $<0.001$ & $<0.001$ & $<0.001$ \\
\hline $\begin{array}{l}\text { Incorporation tillage (Inc } \\
\text { Tillage) }\end{array}$ & $<0.001$ & $<0.001$ & $<0.001$ & 0.003 & 0.505 & 0.489 & 0.519 \\
\hline Top-dressing (Top) & $<0.001$ & $<0.001$ & $<0.001$ & $<0.001$ & 0.504 & 0.395 & $<0.001$ \\
\hline Year & $<0.001$ & $<0.001$ & $<0.001$ & $<0.001$ & $<0.001$ & $<0.001$ & $<0.001$ \\
\hline Fert $\times$ Inc Tillage & 0.388 & 0.046 & 0.565 & 0.076 & 0.963 & 0.796 & $<0.001$ \\
\hline Fert $\times$ Top & 0.152 & 0.452 & 0.628 & 0.007 & $<0.001$ & 0.418 & $<0.001$ \\
\hline Fert $\times$ Year & $<0.001$ & 0.006 & $<0.001$ & $<0.001$ & $<0.001$ & 0.053 & $<0.001$ \\
\hline Inc Tillage $\times$ Top & 0.731 & 0.569 & 0.479 & 0.047 & 0.363 & 0.573 & 0.567 \\
\hline Inc Tillage $\times$ Year & $<0.001$ & 0.127 & 0.092 & 0.036 & $<0.001$ & 0.037 & 0.008 \\
\hline Top $\times$ Year & 0.002 & 0.180 & 0.026 & $<0.001$ & $<0.001$ & 0.217 & $<0.001$ \\
\hline Fert $\times$ Inc Tillage $\times$ Top & 0.513 & 0.360 & 0.815 & 0.174 & 0.191 & 0.624 & 0.508 \\
\hline Fert $\times$ Inc Tillage $\times$ Year & 0.010 & 0.038 & 0.235 & 0.014 & 0.016 & 0.443 & $<0.001$ \\
\hline Fert $\times$ Top $\times$ Year & 0.094 & 0.002 & 0.084 & 0.333 & 0.012 & 0.380 & $<0.001$ \\
\hline Inc Tillage $\times$ Top $\times$ Year & 0.767 & 0.341 & 0.650 & 0.271 & 0.077 & 0.963 & 0.207 \\
\hline $\begin{array}{l}\text { Fert } \times \text { Inc } \\
\quad \text { Tillage } \times \text { Top } \times \text { Year }\end{array}$ & 0.862 & 0.933 & 0.986 & 0.201 & 0.454 & 0.746 & 0.106 \\
\hline
\end{tabular}

Different lower-case letters indicate significant differences between treatments at $P<0.05$. 

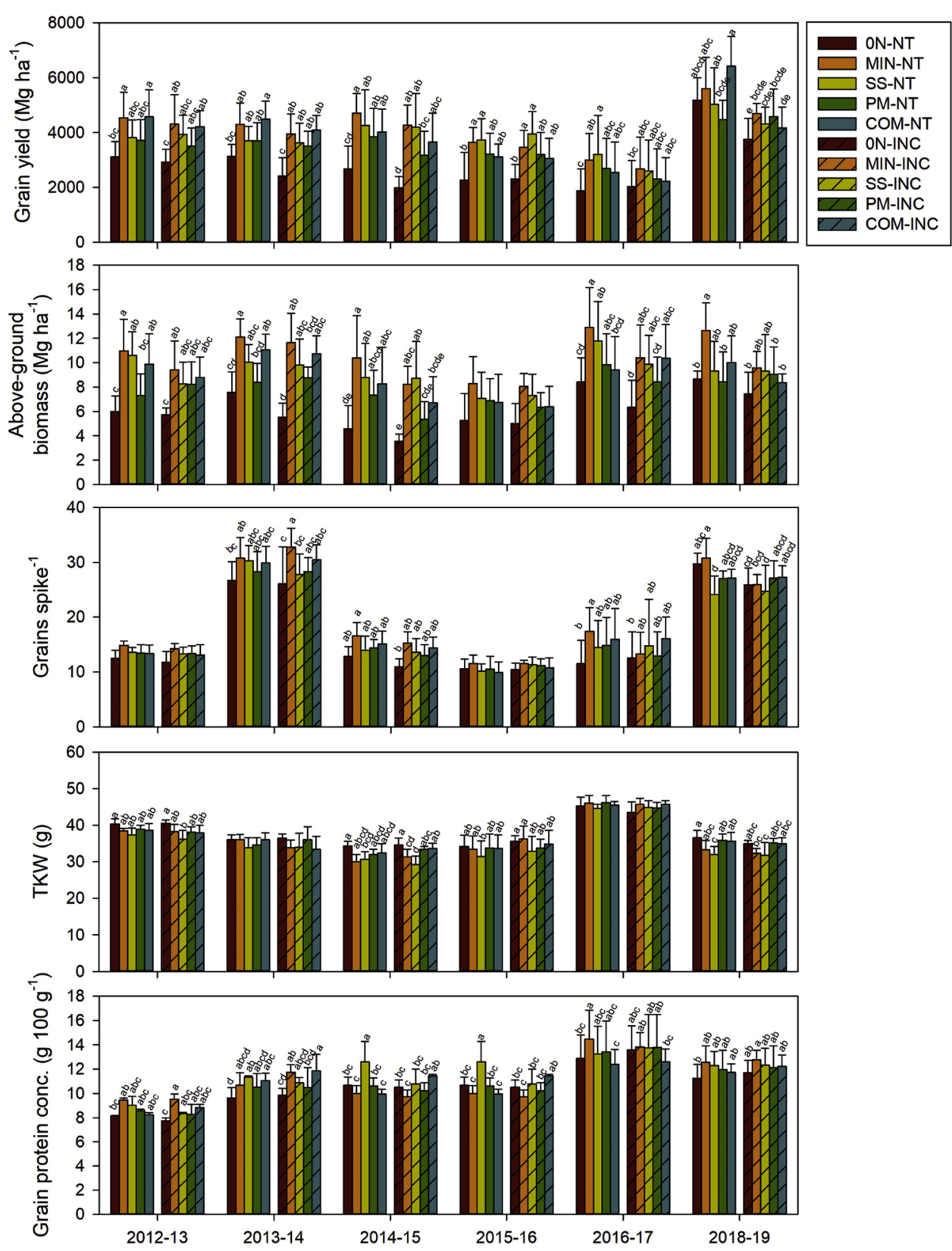

Fig. 3. Winter cereal grain yield, above-ground biomass, grains spike ${ }^{-1}$, thousand kernel weight (TKW) and grain protein concentration as affected by pre-plant fertilization $(0 \mathrm{~N}$, control without $\mathrm{N}$ fertilizer; MIN, mineral $\mathrm{N}$ at $75 \mathrm{~kg} \mathrm{~N}$ $\mathrm{ha}^{-1}$; SS, swine slurry at $75 \mathrm{~kg} \mathrm{~N} \mathrm{ha}{ }^{-1}$; PM, poultry manure at $75 \mathrm{~kg} \mathrm{~N}^{-1}$; COM, compost at $75 \mathrm{~kg} \mathrm{~N} \mathrm{ha}^{-1}$ ), incorporation (NT, no-tillage without incorporating the fertilizers; INC, incorporation of the fertilizer with a 5-cm depth pass of a vibrocultivator), cropping season and their interactions. For a given cropping season, letters indicate differences between treatments at $P<0.05$. Vertical bars correspond to standard deviation. differences were observed between the control treatments (0 N-NT and $0 \mathrm{~N}$-INC) and their fertilized counterparts. Season 2018-19, the most productive, was unique showing differences on grain yield between fertilized treatments with $43 \%$ greater yield in COM-NT than in PM-NT (Fig. 3). Although no significant differences were found between preplant fertilizer types in most of the years a trend of greater yield was observed in MIN and SS compared to the rest (Fig. 3). The use of UAN increased crop yield in all the cropping seasons studied by an average of $587 \mathrm{~kg}$ grain ha ${ }^{-1}$, which represents an $18 \%$ of the total annual production. Winter cereal above-ground biomass was significantly affected by pre-plant fertilization $\times$ incorporation $\times$ year interaction and the pre-plant fertilization $\times \mathrm{N}$ top dressing $\times$ year interaction (Table 3 ). In this regard, MIN-NT produced $50 \%, 44 \%$, and $50 \%$ more biomass than PM-NT in 2012-13, 2013-14, and 2018-19, respectively, SS-NT produced $20 \%$ more biomass than PM-NT in 2014-15, and MIN-NT produced $37 \%$ more biomass than COM-NT in 2016-17 (Fig. 3). Differently to grain yield, no differences between -NT and -INC were observed on above-ground biomass for each pre-plant fertilization treatment. Compared to the $0 \mathrm{~N}$ treatment, the use of pre-plant fertilization plus UAN increased above-ground biomass in most of the cropping seasons (Fig. 4). Moreover, for a given pre-plant fertilization treatment, the application of UAN compared to the no application (UAN + vs. UAN-) led to greater above-ground biomass in 2014-15 and 2018-19 when using SS, and in 2016-17 in $0 \mathrm{~N}$ (Fig. 4). The number of spikes meter ${ }^{-2}$ was affected by the top dressing $\times$ year, and fertilization $\times$ year interactions and by the incorporation. In this regard, the application of UAN increased the number of spikes meter ${ }^{-2}$ by a $25 \%$ in one cropping season (2014-15) (data not shown). Differences between pre-plant fertilization treatments occurred in 2012-13 and 2015-16 with greater spikes $\mathrm{m}^{-2}$ in the fertilized treatments compared to $0 \mathrm{~N}$, and in 2014-15 with the greatest values under MIN and SS, medium under $\mathrm{COM}$ and PM and the lowest under $0 \mathrm{~N}$ (data not shown). Finally, the incorporation of the pre-plant fertilizers decreased the spikes $\mathrm{m}^{-2}$ with 676 and 632 spikes $\mathrm{m}^{-2}$ for the NT and INC treatments, respectively, as an average of all cereal cropped seasons. The number of kernels spike ${ }^{-1}$ was affected by the pre-plant fertilization $\times$ incorporation $\times$ season 

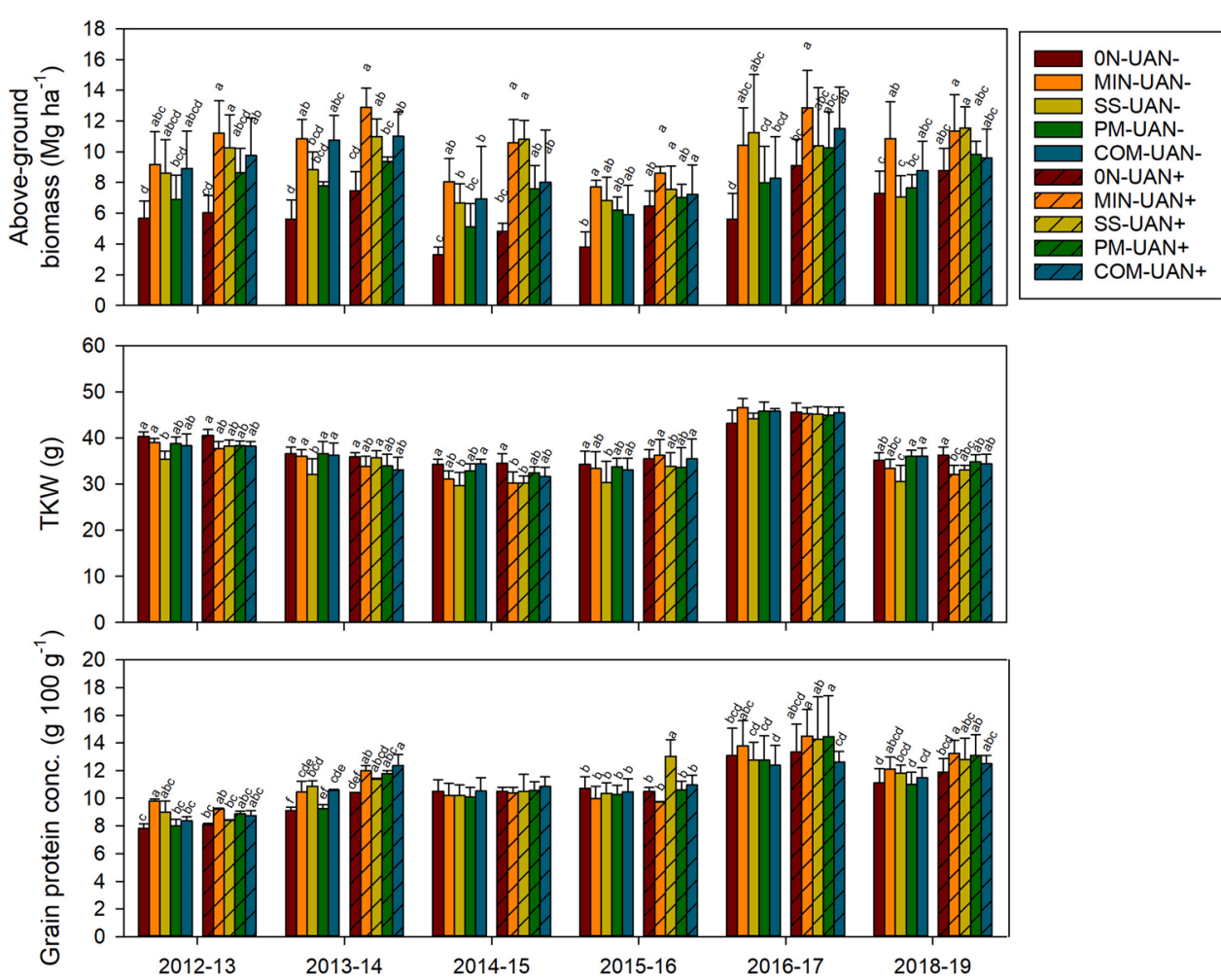

Fig. 4. Winter cereal above-ground biomass, thousand kernel weight (TKW) and grain protein concentration as affected by pre-plant fertilization $(0 \mathrm{~N}$, control without $\mathrm{N}$ fertilizer; MIN, mineral $\mathrm{N}$ at $75 \mathrm{~kg} \mathrm{~N}$ ha $^{-1}$; SS, swine slurry at $75 \mathrm{~kg} \mathrm{~N}^{-1}$; $\mathrm{PM}$, poultry manure at $75 \mathrm{~kg} \mathrm{~N} \mathrm{ha}^{-1}$; COM, compost at $75 \mathrm{~kg} \mathrm{~N} \mathrm{ha}^{-1}$ ), top dressing $\mathrm{N}$ fertilization (UAN-, control without fertilizer; $\mathrm{UAN}+, 50 \mathrm{~kg} \mathrm{~N} \mathrm{ha}^{-1}$ as UAN), cropping season and their interactions. For a given cropping season, letters indicate differences between treatments at $P<0.05$. Vertical bars correspond to standard deviation. interaction, and by the top dressing $\times$ season, incorporation $\times$ top dressing, and fertilization $\times$ top dressing interactions (Table 3 ). Seasons 2013-14 and 2018-19 presented higher number of kernels spike ${ }^{-1}$ compared to the rest. In 2013-14 no differences were observed between NT treatments while $18-25 \%$ greater number of kernels spike ${ }^{-1}$ was observed in MIN-INC compared to $0 \mathrm{~N}$-INC and SS-INC (Fig. 3). In 2016-17, significant differences on the number of kernels spike ${ }^{-1}$ were observed between MIN-NT and 0 N-NT and 0 N-INC with lower values in the two last while intermediate values were observed in the rest of treatments. Finally, in 2018-19, greater number of kernels spike ${ }^{-1}$ were observed in MIN-NT compared to SS-NT, 0 N-INC, MIN-INC and SS-INC (Fig. 3). Weight kernel $^{-1}$ was affected by the pre-plant fertilization $\times$ incorporation $\times$ year interaction and by the pre-plant fertilization $\times \mathrm{N}$ top dressing $\times$ year interaction (Table 3 ). For the first, a trend of higher TKW was observed in the control treatments (0 N-NT and $0 \mathrm{~N}$-INC) compared to their MIN and SS counterparts in 2012-13, 2014-15, 2015-16, and 2018-19 (Fig. 3). In the treatments without UAN (UAN-) the SS treatment presented the lowest TKW in 2012-13, 2013-14, 2014-15, 2015-16, and 2018-19 (Fig. 4). The use of UAN (UAN + vs. UAN-) only increased the TKW by $13 \%$ under one pre-plant fertilization treatment (SS) in the 2013-14 cropping season (Fig. 4). The harvest index (HI) was significantly affected by the pre-plant fertilization. As an average of seasons $0 \mathrm{~N}$ presented the greatest $\mathrm{HI}(0.48)$ and the SS the lowest (0.44) with intermediate values shown by the PM (0.47), COM (0.47) and MIN (0.46) treatments (Table 3). The incorporation $\times$ year interaction had a significant effect on $\mathrm{HI}(\mathrm{p}=0.037)$ that did not produce differences between treatments according to the Tukey test. Winter cereal grain protein concentration was significantly affected by the pre-plant fertilization $\times$ incorporation $\times$ year interaction, and by the pre-plant fertilization $\times \mathrm{N}$ top dressing $\times$ year interaction (Table 3 ). Regarding to the pre-plant fertilization $\times$ incorporation $\times$ year interaction, in 2012-13 the MIN-INC had $23 \%$ greater grain protein concentration compared to $0 \mathrm{~N}-\mathrm{INC}$. In 2013-14 $18 \%$ and $15 \%$ greater grain protein concentration was found in SS-NT and COM-NT compared to $0 \mathrm{~N}-\mathrm{NT}$, respectively, while in the incorporated treatments the MININC and COM-INC had $19 \%$ and $20 \%$ greater values compared to
0 N-INC, respectively. In 2014-15 and 2015-16 greater grain protein concentration was found in SS-NT had greater grain protein concentration compared to the rest of -NT treatments while COM-INC showed greater values than MIN-INC. In 2016-17 MIN-NT had $10 \%$ greater grain protein concentration than COM-NT. Incorporating pre-plant fertilizer increased grain protein concentration only in 2014-15 and 2015-16 when using SS (Fig. 3). Grain protein concentration in 2013-14 increased with UAN for MIN, PM, and COM treatments, in 2015-16 for SS, in 2016-17 for SS and PM, and in 2018-19 for PM (Fig. 4).

\subsection{Pre-plant and top dressing $N$ fertilization and incorporation impact on winter cereal water and nitrogen-related indicators}

Winter cereal water use (WU) was significantly affected by the preplant fertilization $\times$ year, incorporation $\times$ year and top dressing $\times$ year interactions (Table 4). In 2012-13 there was 4\% greater WU in SS compared to MIN and the $0 \mathrm{~N}, \mathrm{PM}$ and COM had intermediate values while in 2014-15 WU was greater for MIN and COM compared to the $0 \mathrm{~N}$ and SS and PM had intermediate values (Fig. 6). Top dressing $\mathrm{N}$ application only increased WU in $2015-16$ by $3 \%$ (data not shown). Water use efficiency for biomass $\left(\mathrm{WUE}_{\mathrm{b}}\right.$ ) was affected by the interaction between pre-plant fertilization, $\mathrm{N}$ top dressing and year and by the incorporation of the fertilizers (Table 4). From 2012-13 to 2016-17 the use of pre-plant fertilizer increased $\mathrm{WUE}_{\mathrm{b}}$ compared to the $0 \mathrm{~N}$ treatment independently of the use of UAN. However, for a given cropping season and UAN treatment no differences between pre-plant fertilization treatments were found on $\mathrm{WUE}_{\mathrm{b}}$ (Fig. 5). The incorporation of the preplant fertilizer reduced $W_{U} E_{b}$ by a $10 \%$ from $24.3-21.8 \mathrm{~kg}$ $\mathrm{ha}^{-1} \mathrm{~mm}^{-1}$ (Table 4). The WUE was affected by the pre-plant fertilization $\times \mathrm{N}$ top dressing, pre-plant fertilization $\times$ year, and incorporation $\times$ year interactions (Table 4 ). The application of UAN increased WUE $_{\mathrm{y}}$ by $18 \%, 15 \% 14 \%$ and $10 \%$ under SS, MIN, PM and COM, while the incorporation of the pre-plant fertilizer only increased $W_{U E}$ in 2018-19. From 2012-13 to 2015-16 differences between pre-plant fertilizers on WUE $\mathrm{W}_{\mathrm{y}}$ were found (Fig. 6), generally, with the greatest 
Table 4

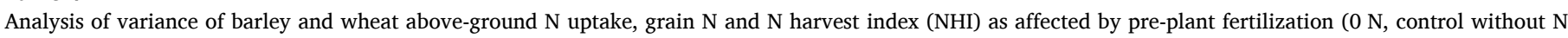

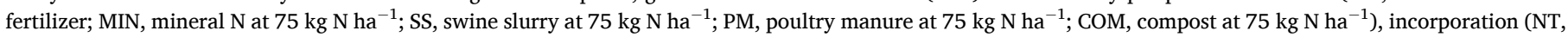

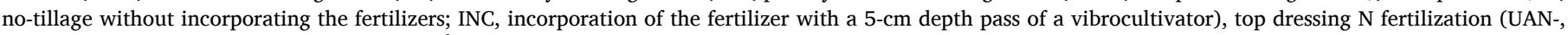
control without fertilizer; UAN,$+ 50 \mathrm{~kg} \mathrm{~N}^{-1}$ as UAN), year and their interactions.

\begin{tabular}{|c|c|c|c|c|c|c|c|}
\hline Treatments & $\begin{array}{l}\text { WU } \\
(\mathrm{mm})\end{array}$ & $\begin{array}{l}\text { WUE }_{\mathrm{b}}(\mathrm{kg} \\
\left.\mathrm{ha}^{-1} \mathrm{~mm}^{-1}\right)\end{array}$ & $\begin{array}{l}\text { WUE }_{\mathrm{y}}(\mathrm{kg} \\
\left.\mathrm{ha}^{-1} \mathrm{~mm}^{-1}\right)\end{array}$ & $\begin{array}{l}\text { N uptake (kg N } \\
\left.\mathrm{ha}^{-1}\right)\end{array}$ & $\begin{array}{l}\text { Grain N (kg N } \\
\left.\text { ha }^{-1}\right)\end{array}$ & NHI & $\begin{array}{l}\text { NUE }\left(\mathrm{kg} \mathrm{ha}^{-1} \mathrm{~kg}^{-1}\right. \\
\text { N) }\end{array}$ \\
\hline $0 \mathrm{~N}$ & 365.5 & 16.8 & 7.8 & 74.5 & 53.2 & 0.71 & 20.8 \\
\hline MIN & 370.8 & 28.0 & 10.9 & 129.9 & 90.2 & 0.69 & 16.4 \\
\hline SS & 373.3 & 24.9 & 10.2 & 113.2 & 78.2 & 0.69 & 14.6 \\
\hline PM & 371.9 & 21.2 & 9.5 & 92.7 & 67.3 & 0.72 & 14.4 \\
\hline $\mathrm{COM}$ & 371.5 & 24.0 & 10.6 & 106.4 & 78.5 & 0.73 & 16.3 \\
\hline NT & 371.3 & $24.3 \mathrm{a}$ & 10.3 & 108.9 & 77.2 & 0.70 & 16.6 \\
\hline INC & 370.0 & $21.8 \mathrm{~b}$ & 9.3 & 97.7 & 69.8 & 0.71 & 16.4 \\
\hline UAN- & 369.2 & 20.7 & 9.0 & 87.5 & 62.5 & 0.71 & 18.6 \\
\hline $\begin{array}{l}\text { UAN }+ \\
\text { ANOVA (p-values) }\end{array}$ & 372.0 & 25.3 & 10.6 & 119.2 & 84.5 & 0.70 & 14.5 \\
\hline Fertilization (Fert) & 0.135 & $<0.001$ & $<0.001$ & $<0.001$ & $<0.001$ & $<0.001$ & $<0.001$ \\
\hline $\begin{array}{l}\text { Incorporation tillage (Inc } \\
\text { Tillage) }\end{array}$ & 0.172 & $<0.001$ & $<0.001$ & $<0.001$ & $<0.001$ & 0.306 & 0.027 \\
\hline Top-dressing (Top) & 0.079 & $<0.001$ & $<0.001$ & $<0.001$ & $<0.001$ & 0.195 & $<0.001$ \\
\hline Year & $<0.001$ & $<0.001$ & $<0.001$ & $<0.001$ & $<0.001$ & $<0.001$ & $<0.001$ \\
\hline Fert $\times$ Inc Tillage & 0.687 & 0.248 & 0.131 & 0.003 & 0.015 & 0.923 & 0.158 \\
\hline Fert $\times$ Top & 0.454 & 0.806 & 0.016 & 0.082 & 0.227 & 0.122 & $<0.001$ \\
\hline Fert $\times$ Year & $<0.001$ & 0.058 & $<0.001$ & $<0.001$ & $<0.001$ & $<0.001$ & 0.021 \\
\hline Inc Tillage $\times$ Top & 0.732 & 0.992 & 0.395 & 0.740 & 0.664 & 0.434 & 0.173 \\
\hline Inc Tillage $\times$ Year & 0.048 & 0.205 & $<0.001$ & 0.033 & 0.015 & 0.142 & 0.024 \\
\hline Top $\times$ Year & 0.009 & 0.121 & 0.138 & 0.001 & 0.002 & 0.527 & $<0.001$ \\
\hline Fert $\times$ Inc Tillage $\times$ Top & 0.196 & 0.627 & 0.976 & 0.360 & 0.278 & 0.273 & 0.473 \\
\hline Fert $\times$ Inc Tillage $\times$ Year & 0.645 & 0.519 & 0.069 & 0.026 & 0.036 & 0.132 & 0.355 \\
\hline Fert $\times$ Top $\times$ Year & 0.104 & 0.014 & 0.252 & $<0.001$ & $<0.001$ & 0.051 & 0.004 \\
\hline Inc Tillage $\times$ Top $\times$ Year & 0.248 & 0.979 & 0.963 & 0.587 & 0.693 & 0.979 & 0.110 \\
\hline Fert $\times$ Inc Tillage $\times$ Top $\times$ Year & 0.742 & 0.968 & 0.959 & 0.804 & 0.519 & 0.385 & 0.886 \\
\hline
\end{tabular}

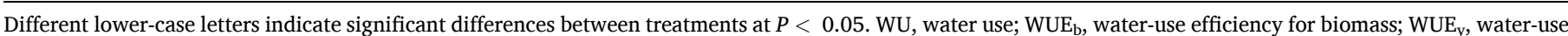
efficiency for yield; NHI, nitrogen harvest index; NUE, nitrogen use efficiency.

values under MIN and COM, intermediate under SS and PM and the lowest in $0 \mathrm{~N}$ (Fig. 6). Winter cereal $\mathrm{N}$ uptake and grain $\mathrm{N}$ were affected by the pre-plant fertilization $\times$ incorporation $\times$ year and the pre-plant fertilization $\times$ top dressing $\times$ year interactions (Table 4). In most years, the MIN treatment led to greater $\mathrm{N}$ uptake compared to $0 \mathrm{~N}$ and in some years compared to PM, while UAN increased $\mathrm{N}$ uptake in some year $\times$ pre-plant fertilization scenarios (Fig. 5).

Mineralized soil $\mathrm{N}$ was estimated at $51 \mathrm{~kg} \mathrm{~N}^{-1}$ with no difference between NT and INC. Nitrogen harvest index was significantly affected by the pre-plant fertilization $\times$ year interaction. Significant differences between pre-plant fertilizers were observed in 2013-14 with higher NHI under SS, PM and COM compared to $0 \mathrm{~N}$ and MIN (Fig. 6). Winter cereal NUE was affected by the incorporation $\times$ year interaction with 13 $\%$ greater NUE under NT than INC in 2018-19 and by the pre-plant fertilization $\times$ top dressing $\times$ year interaction (Table 4). In 2012-13 with UAN- $0 \mathrm{~N}$ had greater NUE than the other pre-plant fertilization strategies, while in some years such as 2014-15 and 2018-19 the use of UAN decreased the NUE, independently of the pre-plant fertilization strategy used (Fig. 5). In our experiment NUE diminished significantly when increasing $\mathrm{N}$ supply (which encompassed residual soil $\mathrm{N}$, soil $\mathrm{N}$ mineralization, and $\mathrm{N}$ fertilizers) from values close to $30 \mathrm{~kg} \mathrm{ha}^{-1} \mathrm{~kg}^{-1} \mathrm{~N}$ for a N supply around $100 \mathrm{~kg} \mathrm{~N}^{-1}$ to values as low as $7 \mathrm{~kg} \mathrm{ha}^{-1} \mathrm{~kg}^{-1} \mathrm{~N}$ (Fig. 7). Our data showed no statistically significant response of WUE to $\mathrm{N}$ supply, but the mean WUE $\mathrm{y}$ was $9.8 \mathrm{~kg} \mathrm{ha}^{-1} \mathrm{~mm}^{-1}$.

\section{Discussion}

\subsection{Pre-plant $N$ fertilization impacts on winter cereal performance}

Although the response of winter cereals to organic fertilizers and placement methods has been researched widely (Edmeades, 2003; Nkebiwe et al., 2016), similar studies are limited for semiarid European no-tilled agroecosystems.

Pre-plant organic fertilizers and MIN performed similarly but increased the grain yield, above-ground biomass, $\mathrm{N}$ uptake and grain $\mathrm{N}$ compared to $0 \mathrm{~N}$. The SS is the closest in composition to a MIN fertilizer since most of the N in SS is found as ammonium, which under the aerobic conditions of the Mediterranean pedoclimatic conditions is rapidly oxidized to nitrate (Plaza-Bonilla et al., 2018). Differently, most of the $\mathrm{N}$ contained in $\mathrm{PM}$ and $\mathrm{COM}$ is present in organic forms and must undergo a complete mineralization process to be available for crops. The rates of $\mathrm{N}$ mineralization-immobilization of animal excretions depend on $\mathrm{C}$ mineralization rate and their $\mathrm{C}$ to $\mathrm{N}$ ratio (Morvan and Nicolardot, 2009). Delayed mineralization leads to reduced $\mathrm{N}$ availability of organic fertilization during the reproductive stages of winter cereals. This constraint is normally overcome after several years of organic fertilizer application, which enhances the mineralization of organic nitrogen (Rossini et al., 2018). Nonetheless, even under the clear differences in $\mathrm{N}$ composition of the organic fertilizers tested, winter cereal production was similar between the different pre-plant fertilizers and there was only a decreasing trend in yield with the sources that would be expected to have less initial $\mathrm{N}$ availability.

The lack of differences between pre-plant fertilizers on winter cereal production could be the result of high (approximately $100 \mathrm{~kg} \mathrm{~N} \mathrm{ha}^{-1}$ in the $0-60 \mathrm{~cm}$ soil depth average across sampling dates) levels of SMN in the fertilized treatments. In addition, annual soil $\mathrm{N}$ mineralization was estimated at $51 \mathrm{~kg} \mathrm{~N} \mathrm{ha}^{-1}$, which is similar to $41 \mathrm{~kg} \mathrm{~N} \mathrm{ha}^{-1}$ estimated by Plaza-Bonilla et al. (2017) in a slightly drier area under no-tillage. Typically, under similar conditions there is low $\mathrm{N}$ loss through nitrate leaching and $\mathrm{N}_{2} \mathrm{O}$ emission (Jiménez-de-Santiago et al., 2019; Plaza-Bonilla et al., 2014) and ammonia volatilization is the main loss pathway of reactive $\mathrm{N}$ (Yaguie et al., 2019). The combination of soil $\mathrm{N}$ mineralization and low $\mathrm{N}$ loss potential likely explains the lack of differential response among fertilizer types in our experiment. Differently, other authors have reported decrease in crop yield for organic fertilizers compared to mineral ones in Mediterranean conditions (Rossini et al., 2018) while other, like Plaza-Bonilla et al. (2017), observed greater barley yield when using 75 or $150 \mathrm{~kg} \mathrm{~N} \mathrm{ha}^{-1}$ as swine slurry compared to 

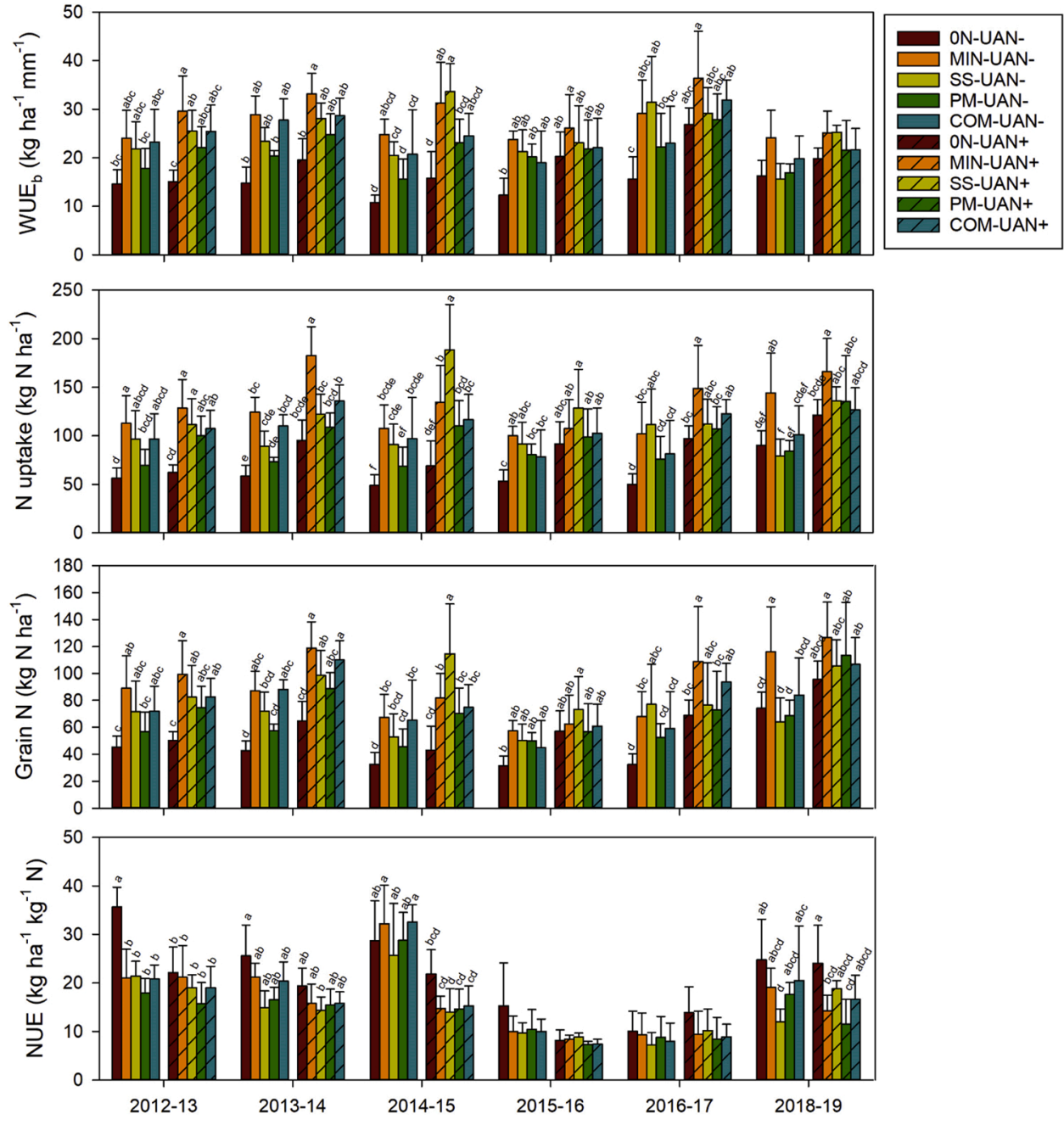

Fig. 5. Winter cereal water-use efficiency for yield $\left(W_{U} E_{y}\right), N$ uptake, grain $\mathrm{N}$ and nitrogen use efficiency (NUE) as affected by pre-plant fertilization $(0 \mathrm{~N}$, control without $\mathrm{N}$ fertilizer; MIN, mineral $\mathrm{N}$ at $75 \mathrm{~kg} \mathrm{~N}$ ha $^{-1}$; SS, swine slurry at $75 \mathrm{~kg} \mathrm{~N}^{-1}$; $\mathrm{PM}$, poultry manure at $75 \mathrm{~kg} \mathrm{~N}$ ha $^{-1}$; COM, compost at $75 \mathrm{~kg} \mathrm{~N}^{-1}$ ), top dressing $\mathrm{N}$ fertilization (UAN-, control without fertilizer; UAN+, $50 \mathrm{~kg} \mathrm{~N} \mathrm{ha}{ }^{-1}$ as UAN), cropping season and their interactions. For a given cropping season, letters indicate differences between treatments at $P<0.05$. Vertical bars correspond to standard deviation. the same $\mathrm{N}$ rate of mineral fertilizer in a slightly drier area of the Ebro Valley. Although the impact of different pre-plant fertilizers on grain yield was non-significant, greater above-ground biomass production was observed under MIN-NT than PM-NT in 2012-13, 2013-14, under MIN-NT than COM-NT in 2016-17, and under SS-NT than PM-NT in 2018-19. This may be related to availability of mineral $\mathrm{N}$ and concomitant production of crop biomass during early stages of crop development. The presence of nitrogen when water is available at the first crop stages often leads to an increase in vegetative growth at great expense of water used by transpiration (Plaza-Bonilla et al., 2017). In this regard, our data also indicated a greater WU in some of the cropping seasons studied when using MIN and SS, and in some cases under COM, which would indicate the impact of readily $\mathrm{N}$ available forms in early consumption of soil water and increase in the production of crop biomass. The greater TKW observed in $0 \mathrm{~N}$ compared to their MIN and SS counterparts in $2012-13,2014-15,2015-16$, and 2018-19 could be explained by a greater water utilization through transpiration when mineral $\mathrm{N}$ is available at the first stages of crop growth reducing the amount of soil water available during the grain filling period.

Independent of the type of pre-plant fertilizer used, $W_{U} E_{b}$ was higher than the $0 \mathrm{~N}$ treatment in most of the cropping seasons. Similarly, the application of pre-plant fertilizers increased the WUE $\mathrm{y}_{\mathrm{y}}$ compared to the $0 \mathrm{~N}$ treatment, with a trend of greater impact when using MIN and COM than when using SS and PM. These results are in line with the findings of the meta-analysis performed by Wang et al. (2020) in northern China who found an increase in wheat WUE when using organic fertilizers compared to $0 \mathrm{~N}$, mainly when grain yield was below $4 \mathrm{Mg} \mathrm{ha}^{-1}$. An increase in crop transpiration and a reduction of soil water evaporation due to higher leaf area index could explain the higher water use efficiency of the crop in the fertilized treatments (Cantero-Martínez et al., 2003). However, an increase in $\mathrm{N}$ supply trying to maximize $\mathrm{WUE}_{\mathrm{y}}$ has a deleterious impact on NUE as shown by Sadras and Rodriguez (2010) when working in Mediterranean environments. This trade-off is particularly important in low rainfall environments with high nitrogen-to-grain price ratio, such as the ones relying solely on synthetic fertilizers. Our results are in line with the findings from the literature with a significant diminution of NUE when increasing N supply.

\subsection{Fertilization incorporation and $N$ top dressing impacts on winter cereal performance}

The reduction of ammonia volatilization after the application of slurries and manures in no-tilled cropping systems is challenging. Although disk and tine coulter injection systems exist they often cause significant soil disturbance and residue incorporation, increasing the risk of soil erosion (Dell et al., 2012) and under dry conditions they require greater power and, concomitantly, they usually imply greater costs. In our experiment the implementation of a shallow incorporation of the pre-plant fertilizers with a vibrocultivator led to a slight decrease in the amount of soil water stored which was probably the cause for the lower production of the crop and the lower NUE in the 2018-19 season that was the most productive season. Crop above-ground biomass was not affected by the incorporation of the fertilizer, differently than the amount of spikes meter ${ }^{-2}$ that was reduced when incorporating the 

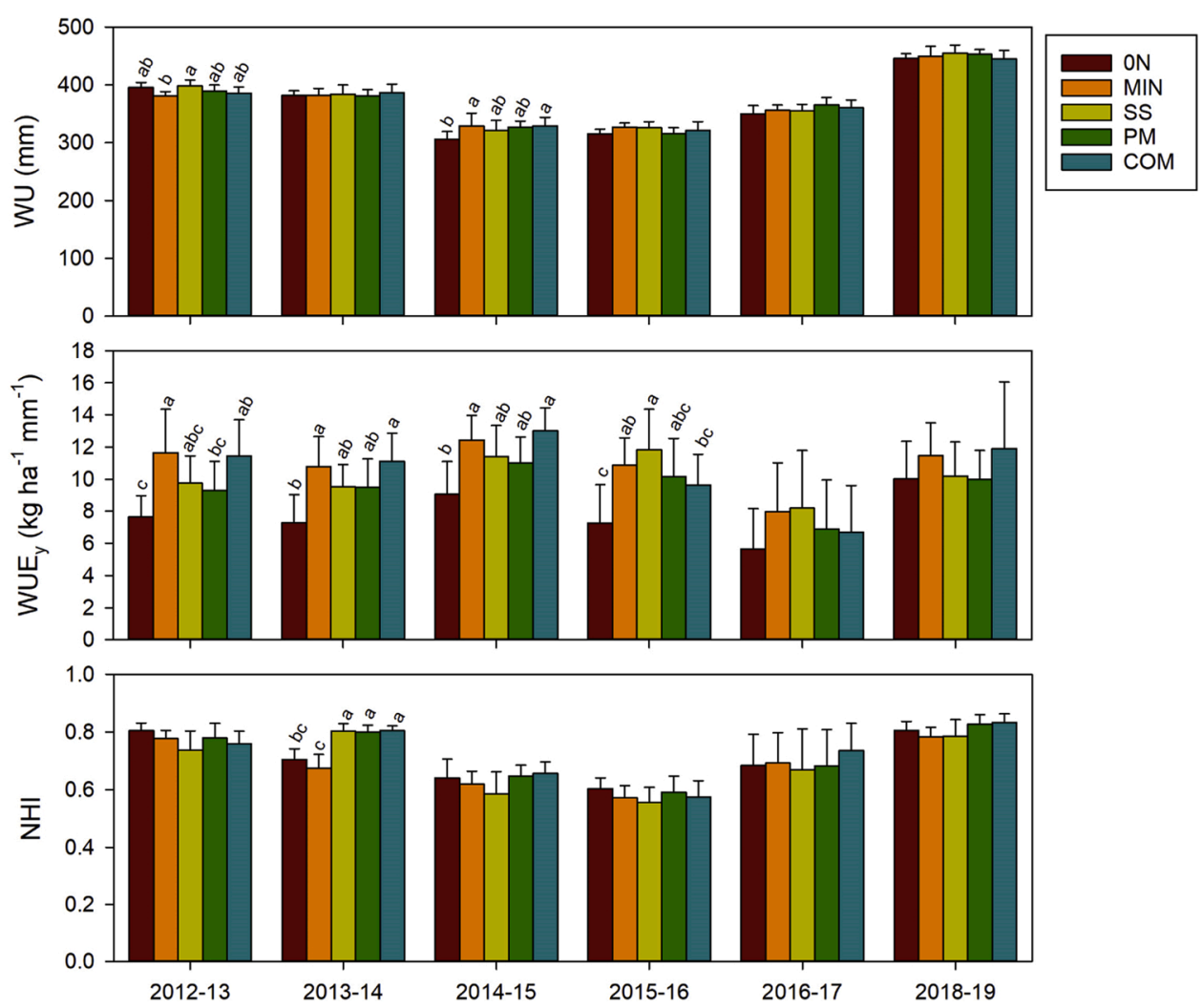

Fig. 6. Winter cereal water use, water use efficiency for yield $\left(\mathrm{WUE}_{\mathrm{y}}\right)$ and nitrogen harvest index $(\mathrm{NHI})$ as affected by pre-plant fertilization (0 N, control without $\mathrm{N}$ fertilizer; MIN, mineral $\mathrm{N}$ at $75 \mathrm{~kg} \mathrm{~N} \mathrm{ha}^{-1}$; SS, swine slurry at $75 \mathrm{~kg} \mathrm{~N} \mathrm{ha}^{-1}$; PM, poultry manure at $75 \mathrm{~kg} \mathrm{~N} \mathrm{ha}^{-1}$; COM, compost at $75 \mathrm{~kg} \mathrm{~N}^{-1}$ ), cropping season and their interactions. For a given cropping season, letters indicate differences between treatments at $P<0.05$. Vertical bars correspond to standard deviation.

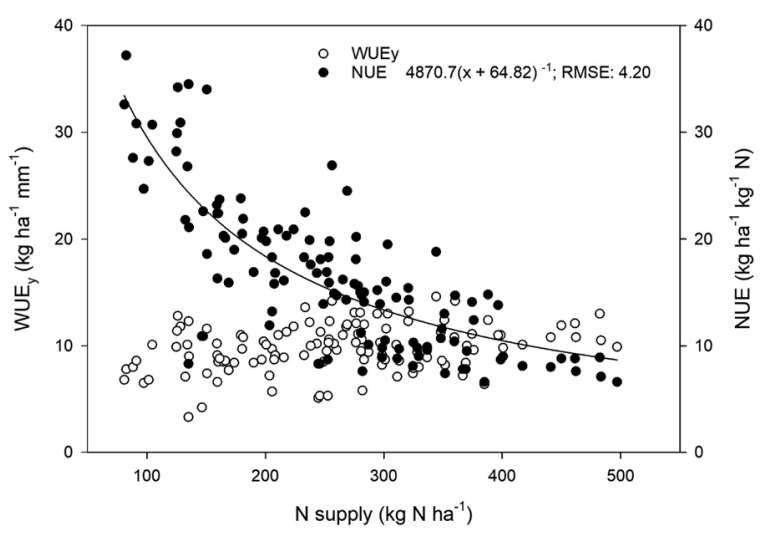

Fig. 7. Water use efficiency for yield (WUE $)$ and nitrogen use efficiency (NUE) as affected by $\mathrm{N}$ supply. Each dot represents one treatment $\times$ cropping season combination.

fertilizer. In turn, according to the significant pre-plant fertilization $\times$ incorporation tillage $\times$ year interaction, the use of incorporation tillage when SS was applied in 2014-2015 and in 2015-2016 led to a reduction in grain protein compared to NT. Contrarily to what could be expected the potential reduced volatilization when incorporating the fertilizer did not improve grain protein concentration. These results would suggest a greater limitation of the crop by water availability. Then, the lack of water during the early reproductive period of the crop could have reduced the uptake of $\mathrm{N}$ during grain filling in years of dry springs such as 2014-2015. Similarly, the incorporation of the pre-plant fertilizers reduced $W_{U} E_{b}$ by $10 \%$ from $24.3-21.8 \mathrm{~kg} \mathrm{ha}^{-1} \mathrm{~mm}^{-1}$, which indicates the limitations of shallow tillage passes to incorporate the fertilizer in excessively dry conditions like the ones of our experiment. In contrast, when working in a wetter area of Canada, Chen and Samson (2002) observed a slight increase in corn grain yield when incorporating the manure with an aerator. The incorporation of organic fertilizers can reduce ammonia volatilization up to $55 \%$ (Pan et al., 2016; Sommer and Hutchings, 2001), especially for liquid slurries that are rich in ammonium in conjunction with tillage implements that cause significant soil disturbance. However, the impact of low-disturbance incorporation methods such as aerators is not conclusive, with authors reporting decreases in $\mathrm{NH}_{3}$ losses while others show no significant effects (Gordon et al., 2000; Powell et al., 2011). Ammonia losses are reduced when cultivating due to higher infiltration rate of the slurry into the soil, faster reaction of ammonia with the soil and soil water and by an increase surface roughness which diminishes wind at the soil surface. However, a short delay between application and incorporation is key for a significant reduction of the losses of N (Sommer and Hutchings, 2001). Although $\mathrm{NH}_{3}$ losses are usually high in calcareous Mediterranean soils (Yaguie et al., 2019), the potential reduction by shallow tillage incorporation did not lead to crop yield increases in our experiment. This indicates that in Mediterranean conditions where crops are normally fertilized, water availability is a greater limiting factor than $\mathrm{N}$.

Top dressing UAN increased crop yield in all the cropping seasons studied by an average of $587 \mathrm{~kg}$ grain ha ${ }^{-1}$ (Table 3 ) but only increased crop above-ground biomass in few specific cases. This increase in crop production follows what is expected by farmers in rainfed Mediterranean regions that apply top dress $\mathrm{N}$ to overcome yield penalties when relying only on pre-plant organic fertilization based on swine slurries or manures. According to the pre-plant fertilization $\times$ top dressing $\times$ year interaction the use of UAN was key to improve some crop related variables when SS was used as pre-plant fertilizer, which could be explained by a partial counterweighing of $\mathrm{N}$ loss through $\mathrm{NH}_{3}$ volatilization. For instance, the use of UAN (i.e. SS-UAN + treatment) improved barley above-ground biomass, $\mathrm{N}$ uptake, and grain $\mathrm{N}$ in 2014-2015 and in 
2018-2019, grain protein concentration in 2015-2016 and 2016-2017. UAN application in our study also helped increase the $\mathrm{WUE}_{\mathrm{y}}$ in the different pre-plant fertilizers tested (MIN, SS, PM and COM) although only increased grain protein in few pre-plant fertilization $\times$ cropping season combinations. However, the key limitation that represents water availability under rainfed Mediterranean conditions would be shown by the reduction in barley NUE in cropping seasons with very dry springs such as 2014-2015. In that season the use of UAN reduced barley NUE independently of the type of pre-plant fertilizer used (MIN, SS, PM and $\mathrm{COM})$. According to our results in Mediterranean rainfed areas the use of pre-plant organic fertilizers would led to the same winter cereal productivity than mineral ones, while the use of shallow tillage for their incorporation would be counterproductive, given the important limitations of soil water for crop response to $\mathrm{N}$ application. Finally, the use of UAN as top dressing would be recommended to enhance productivity and grain protein concentration in wet years.

\section{Conclusions}

Our study demonstrates that in semiarid Mediterranean systems the pre-sowing application of organic fertilizers based on SS, PM and COM can perform as well as pre-plant mineral $\mathrm{N}$ fertilizer for winter cereal production and water-use efficiency. In these agricultural systems the high levels of residual $\mathrm{N}$ often found plus soil $\mathrm{N}$ mineralization overcome the differences on early season $\mathrm{N}$ availability between these products. The trend of lower grain yield when using solid organic fertilizers compared to mineral $\mathrm{N}$ and SS would suggest that the response of grain yield to organic fertilizers could differ in scenarios with lower soil residual $\mathrm{N}$. The application of a low rate $\left(50 \mathrm{~kg} \mathrm{~N} \mathrm{ha}^{-1}\right)$ of UAN as top dress increased winter cereal grain yield with an average of $587 \mathrm{~kg}$ grain $\mathrm{ha}^{-1} \mathrm{yr}^{-1}$ and increased WUE , compared to the control without UAN. Moreover, our data shows that in rainfed semiarid Mediterranean conditions with severe water limitations, a shallow incorporation of organic fertilizers with a vibrocultivator pass results in soil water loss and reduced winter cereal yields by lowering the number of spikes per $\mathrm{m}^{2}$ compared to the broadcast application of fertilizers on the soil surface. However, even more important is to determine how to balance the goals of increasing productivity by conserving soil-water while mitigating $\mathrm{NH}_{3}$ emissions to the atmosphere. A potential alternative to circumvent these seemingly contradicting goals, could be injection of organic fertilizers. Of course, such application may be more cumbersome, costly (time and money) and requires specialized equipment compared to a broadcast application. Moreover, it could increase soil $\mathrm{N}_{2} \mathrm{O}$ emissions as has been observed in wetter environments. Also the loss of soil-water resulting from the application may still be too great to have a meaningful benefit relative to more intensive tillage alternatives. Proper management of organic fertilizers, product of the intensive animal husbandry of the region, requires a holistic valorization of their nutrients, a more efficient reduction of their volumes, and minimizing farmfield distances by establishing better user networks.

\section{CRediT authorship contribution statement}

Daniel Plaza-Bonilla: Conceptualization, Methodology, Validation, Formal analysis, Investigation, Data curation, Writing - original draft, Writing - review \& editing, Visualization, Funding acquisition. Jorge Lampurlanés: Validation, Formal analysis, Investigation, Data curation, Writing - review \& editing, Visualization. Fabián G. Fernández: Validation, Formal analysis, Writing - review \& editing, Visualization. Carlos Cantero-Martínez: Methodology, Investigation, Resources, Writing - review \& editing, Supervision, Project administration, Funding acquisition.

\section{Declaration of Competing Interest}

\section{Acknowledgements}

We thank Javier Bareche, Silvia Martí and Carlos Cortés for their technical assistance and Albareda family for their willingness to collaborate with on-farm experiments. Daniel Plaza-Bonilla is Ramón y Cajal fellow (RYC-2018-024536-I) co-funded by AEI-MICIU and European Social Fund. This research was supported by the AGL2010-22050C03-01, AGL2013-49062-C4-1-R and AGL2017-84529-C3-3-R grants of the Spanish National Plan of Research.

\section{References}

Angás, P., Lampurlanés, J., Cantero-Martínez, C., 2006. Tillage and N fertilization effects on $\mathrm{N}$ dynamics and barley yield under semiarid Mediterranean conditions. Soil Tillage Res. 87, 59-71.

Cantero-Martínez, C., Angás, P., Lampurlanés, J., 2003. Growth, yield and water productivity of barley (Hordeum vulgare L.) affected by tillage and $\mathrm{N}$ fertilization in Mediterranean semiarid, rainfed conditions of Spain. Field Crops Res. 84, 341-357.

Chen, Y., Samson, R., 2002. Integration of liquid manure into conservation tillage corn systems. Trans. ASAE 45, 629-638.

Cherlet, M., Hutchinson, C., Reynolds, J., Hill, J., Sommer, S., von Maltitz, G., (Eds.), 2018. World Atlas of Desertification, Publication Office of the European Union, Luxembourg.

Clar, E., Pinilla, V., 2011. Path dependence and the modernization of agriculture: a case study of Aragon, 1955-85. Rural Hist. 22, 251-269.

Dell, C.J., Kleinman, P.J.A., Schmidt, J.P., Beegle, D.B., 2012. Low-disturbance manure incorporation effects on ammonia and nitrate loss. J. Environ. Qual. 41, 928-937.

Edmeades, D.C., 2003. The long-term effects of manures and fertilisers on soil productivity and quality: a review. Nutr. Cycl. Agroecosyst. 66, 165-180.

European Parliament and Council of the European Union, 2013. Regulation (EU) No 1307/2013 of the European Parliament and of the Council of 17 December 2013 Establishing Rules for Direct Payments to Farmers Under Support Schemes Within the Framework of the Common Agricultural Policy and Repealing Council Regulation (EC) No 637/2008 and Council Regulation (EC) No 73/2009.

European Union, 1991. Council Directive 91/676/EEC of 12 December Concerning the Protection of Waters against Pollution Caused by Nitrates From Agricultural Sources. Off. J. Eur. Communities, Brussels, Belgium, p. L375.

Federer, W.T., King, F., 2007. Variations on Split Plot and Split Block Experiment Designs. John Wiley and Sons Inc, Hoboken, NJ, p. 270 pp. ISBN: 978-0-470-081495 .

Gordon, R., Patterson, G., Harz, T., Rodd, V., MacLeod, J., 2000. Soil aeration for dairy manure spreading on forage: effect on ammonia volatilization and yield. Can. J. Soil Sci. 80, 319-326.

Guillaumes, E., Carrasco, I., Villar-Mir, J.M., 2006. Response of wheat to additional nitrogen fertilizer application after pig slurry on over-fertilized soils. Agron. Sustain. Dev. 26, 127-133.

Hatfield, J.L., Sauer, T.J., Prueger, J.H., 2001. Managing soils to achieve greater water use efficiency: a review. Agron. J. 93, 271-280.

Jiménez-de-Santiago, D.E., Lidón, A., Bosch-Serra, A.D., 2019. Soil water dynamics in a rainfed Mediterranean agricultural system. Water 11, 799.

Kassam, A., Friedrich, T., Shaxson, F., Pretty, J., 2009. The spread of Conservation Agriculture: justification, sustainability and uptake. Int. J. Agric. Sustain. 7 , 292-320.

Lampurlanés, J., Plaza-Bonilla, D., Álvaro-Fuentes, J., Cantero-Martínez, C., 2016. Longterm analysis of soil water conservation and crop yield under different tillage systems in Mediterranean rainfed conditions. Field Crops Res. 189, 59-67.

Malhi, S.S., Nyborg, M., Solberg, E.D., 1996. Influence of source, method of placement and simulated rainfall on the recovery of ${ }^{15} \mathrm{~N}$-labelled fertilizers under zero tillage. Can. J. Soil Sci. 76, 93-100.

Maresma, A., Ariza, M., Martínez, E., Lloveras, J., Martínez-Casasnovas, J.A., 2016. Analysis of vegetation indices to determine nitrogen application and yield prediction in maize (Zea mays L.) from a standard UAV service. Remote Sens. 8, 973.

Merrill, A.L., Watt, B.K., 1973. Energy value of foods: basis and derivation. Agriculture Handbook No. 74. Agricultural Research Service. United States Department of Agriculture, Washington, DC.

Möller, K., Müller, T., 2012. Effects of anaerobic digestion on digestate nutrient availability and crop growth: a review. Eng. Life Sci. 12, 242-257.

Morvan, T., Nicolardot, B., 2009. Role of organic fraction on C decomposition and N mineralization of animal wastes in soil. Biol. Fertil. Soils 45, 477-486.

Mosier, A.R., 2002. Environmental challenges associated with needed increases in global nitrogen fixation. Nutr. Cycl. Agroecosyst. 63, 101-116.

Nkebiwe, P.M., Weinmann, M., Bar-Tal, A., Müller, T., 2016. Fertilizer placement to improve crop nutrient acquisition and yield: a review and meta-analysis. Field Crops Res. 196, 389-401.

Nkoa, R., 2004. Agricultural benefits and environmental risks of soil fertilization with anaerobic digestates: a review. Agron. Sustain. Dev. 34, 473-492.

Noya, I., Aldea, X., González-García, S., Gasol, C.M., Moreira, M.T., Amores, M.J., Marín, D., Boschmonart-Rives, J., 2017. Environmental assessment of the entire pork value chain in Catalonia - a strategy to work towards Circular Economy. Sci. Total Environ. 589, 122-129.

The authors report no declarations of interest. 
Pan, B., Lam, S.K., Mosier, A., Luo, Y., Chen, D., 2016. Ammonia volatilization from synthetic fertilizers and its mitigation strategies: a global synthesis. Agric. Ecosyst. Environ. 232, 283-289.

Parker, D.B., Gilley, J., Woodbury, B., Kim, K.H., Galvin, G., Bartelt-Hunt, S.L., Li, X., Snow, D.D., 2013. Odorous VOC emission following land application of swine manure slurry. Atmos. Environ. 66, 91-100.

Plaza-Bonilla, D., Cantero-Martínez, C., Álvaro-Fuentes, J., 2010. Tillage effects on soil aggregation and soil organic carbon profile distribution under Mediterranean semiarid conditions. Soil Use Manag. 26, 465-474.

Plaza-Bonilla, D., Álvaro-Fuentes, J., Cantero-Martínez, C., 2013. Soil aggregate stability as affected by fertilization type under semiarid no-tillage conditions. Soil Sci. Soc. Am. J. 77, 284-292.

Plaza-Bonilla, D., Álvaro-Fuentes, J., Arrúe, J.L., Cantero-Martínez, C., 2014. Tillage and nitrogen fertilization effects on nitrous oxide yield-scaled emissions in a rainfed Mediterranean area. Agric. Ecosyst. Environ. 189, 43-52.

Plaza-Bonilla, D., Cantero-Martínez, C., Bareche, J., Arrúe, J.L., Lampurlanés, J., ÁlvaroFuentes, J., 2017. Do no-till and pig slurry application improve barley yield and water and nitrogen use efficiencies in rainfed Mediterranean conditions? Field Crops Res. 203, 74-85.

Plaza-Bonilla, D., Álvaro-Fuentes, J., Bareche, J., Pareja-Sánchez, E., Justes, E., CanteroMartínez, 2018. No-tillage reduces long-term yield-scaled soil nitrous oxide emissions in rainfed Mediterranean agroecosystems: a field and modelling approach. Agric. Ecosyst. Environ. 262, 36-47.

Powell, J.M., Jokela, W.E., Misselbrook, T.H., 2011. Dairy slurry application method impacts ammonia emission and nitrate leaching in no-till corn silage. J. Environ. Qual. 40, 383-393.
Rockström, J., Karlberg, L., 2009. 2. Zooming in on the global hotspots of rainfed agriculture in water-constrained environments. In: Wani, S.P., Rockström, J., Oweis, T. (Eds.), Rainfed Agriculture: Unlocking the Potential. CAB International, pp. 36-43. ISBN: 978-1-84593-389-0.

Rossini, F., Provenzano, M.E., Sestili, F., Ruggeri, R., 2018. Synergistic effect of sulfur and nitrogen in the organic and mineral fertilization of durum wheat: grain yield and quality traits in the Mediterranean environment. Agronomy 8, 189.

Sadras, V.O., Rodriguez, D., 2010. Modelling the nitrogen-driven trade-off between nitrogen utilisation efficiency and water use efficiency of wheat in eastern Australia. Field Crops Res. 118, 297-305.

SAS Institute Inc, 2018. Using JMP ${ }^{14}$. SAS Institute Inc., Cary, NC.

Sommer, S.G., Hutchings, N.J., 2001. Ammonia emission from field applied manure and its reduction - invited paper. Eur. J. Agron. 15, 1-15.

Sommer, S.G., Christensen, B.T., Olesen, J.E., 1991. Effects of temperature, wind speeds and air humidity on ammonia volatilization from surface applied cattle slurry. J. Agric. Sci. 117, 91-100.

Velthof, G.L., Mosquera, J., 2011. The impact of slurry application technique on nitrous oxide emission from agricultural soils. Agric. Ecosyst. Environ. 140, 298-308.

Wang, L., Li, Q., Coulter, J.A., Xie, J., Luo, Z., Zhang, R., Deng, X., Li, L., 2020. Winter wheat yield and water use efficiency response to organic fertilization in northern China: a meta-analysis. Agric. Water Manag. 229, 105934.

Yagüe, M.R., Valdez, A.S., Bosch-Serra, A.D., Ortiz, C., Castellví, F., 2019. A short-term study to compare field strategies for ammonia emission mitigation. J. Environ. Qual. 48, 179-184. 